\title{
Characterization of Tropical Wood Species for Use in Civil Constructions
}

\author{
André Luis Christoforo ${ }^{1, *}$, Karen Ané ris Blecha ${ }^{2}$, André Luis Cerávolo de Carvalho ${ }^{1}$, \\ Luiz Fernando Silva Rezende ${ }^{1}$, Francisco Antonio Rocco Lahr ${ }^{2}$
}

\begin{abstract}
${ }^{1}$ Department of Mechanical En gin eering, Federal University of São João del-Rei (UFSJ), São João del-Rei, 36307-352, Brazil ${ }^{2}$ Department ofStructural Engineer ing, En gineering Schoolof SãoCarlos (EESC/USP), São Carlos, 13566-590, Brazil
\end{abstract}

\begin{abstract}
The wood is one of the most applicable materials in industrial activities due to its availability allied to its satisfactory mechanical properties, presenting a good strength/density relation. Its versatility is fundamental for the large expansion of its use on structure building. The exploration, initially selective, turned to be selective and also predatory, what lead to a shortage, raising systematically the prices until the moment where it was not anymore probable to use it on the quantities registered until then. The solution was to define species, between more than 5.000 varieties in AmazonicaTropical Forest, which could substitute the 100 commercially used ones. However, due to technical limitations, these species cannot be completely characterized, what leads to a misusing of timber, once its behaviour is not known completely when it is under mechanical stresses. This research presents some results of the characterization of the following timber species: Canelão, Envira Branca, Guarajá, Quaruba Rosinha and Breu Vermelho. These species are found close to Sinop (Mato Grosso - Brazil), and the results obtained reveal clearly the potential of each species under mechanical stresses, showing that some of them can be good substitutes to the commonly wood speciesused.
\end{abstract}

Keywords Wood, Characterization, Tropical Species

\section{Introduction}

The wood, one of the most utilized materials on the human history, is directly related to usual human activities like living, overcoming natural obstacles, trans portation and agriculture, a mong others.

Its versatility was always fundamental for the human needs and its wide availability was an important factor for a large expansion on its use in structure building, e.g. bridges, silos and roofs.

The application of timber in structural tasks is due to the highly satisfactory properties of some species like the Aroeira do Sertão (Astroniumurundeuva), Cabreúva Vermelha (Myroxylumbalsamum), Faveiro (Pterodonpubences), Pau Marfim (Balforodendronriedelianum), Peroba Rosa (Aspidospermapolyneuron) and Pinho do Pará (Araucaria angustifolia). However, the indiscriminate exploration of these species since 1880 originated the first shortage warnings [1].

According to Souza[1] the exploration initially selective, and then selective and predatory, happened due to the lack of information about most of wood species. This lead to the

* Corresponding author:

alchristo foro@y ahoo.com.br (André Luis Christoforo)

Published online at http://journal.sapub.org/jce

Copyright (C) 2013 Scientific \& Academic Publishing. All Rights Reserved exploration of the species which were alreadycharacterized, reducing the receptivity of the market to new and no trustable species.

The imminent shortage was responsible for a systematic rising in the prices, until the point where it was not anymore probable to use it on the quantities registered until now.

It is now a new moment to the Brazil wood sector, when it is necessary to define which species can commercially substitute the traditionally used species on structural constructions [2].

It is know that the Tropical Brazilian Forests occupy approximately 2.600.000 square kilo meters on the north and central-west regions of Brazil. According to Gonçalves et al[3], it is estimated that there are more than 5.000 species of trees in Amazonian Tropical Forest, while only about 100 are used commercially and not more than 12 are exported to other countries.

In 1982, while there was a plan of the creation of trading posts for timber, with the objective of increasing the number of exported species, the National Institute of Forest Development[4] reg istered that: less than 100 species were emp loyed on the timber industry on the Amazonian Region; national consumers had about 40 pre ferred species of timber; international consumers had few more than 10 preferred species of timber. This situation lead to a decision point on the research institutes related to timber.

Properties of species originated on the Amazonian 
Tropical Forest, already used for structural purposes, but without complete knowledge of their behavior under mechanical stresses are presented on[5-12].

However, due to technical limitations, it has not been possible to characterize completely the referred species, what leads to a misuse of the timber, without the real knowledge of their behavior under mechanical stresses.

It is important to state that there are still indicatives that the Amazon Tropical Forest is suffering of selective and predatory exploration. The consequences of this reflect on the almost $20 \%$ of the original area a lready devastated in an irreversible way, according to the National Institute of Space Research (INPE) [13], entity related to the Ministry of Science and Technology of Brazil. Thus, it is evident that an attitude needs to be taken to decrease the deforestation rate of the tropical forest, especially:

-Stimulus for the application of procedures to handle forests in an auto-sufficient way;

-Spreading of the available information about alternative species characterized by research institutes;

-Maintenance and development of programs to characterize native species;

-Awareness of the market of timber about the importance of substitution of species.

The present research is inserted in the present scenario, looking for characterize mechanically and physically the Brazilian forest timbers and, in particular, the ones located in Sinop city (MatoGrosso - Brazil), contributing for its rational distribution on the consumer market. It was evaluated too the estimative of the strength properties of the wood species with known the density.

\section{Material and Methods}

In order to proceed with this work, were used five species of timber originated from certified areas of tropical forest, provided by the Syndicate of Timber Industries of Mato Grosso (SINDUSMAD) of Sinop, being these: Canelão (Ocoteasp), Envira Branca (Xylopiasp), Guajará (Micropholisvenulosai), Quaruba Rosinha (Vochysiasp) and Breu Verme lho (Protiumsp).

These species were in pieces with nominal dimensions of $6 \mathrm{~cm} \times 12 \mathrm{~cm} \times 300 \mathrm{~cm}$. These passed by a drying process posteriorly, to reach a mo isture content of $12 \%$, the recommended percentage by ABNT NBR 7190[14]. From these pieces, were extracted the samples for characterization, standardized by the referred standard, with small dimensions and no defects. It is important to state that in future works these species will be characterized considering the pieces with structural dimensions, making possible to analyse differences between them[15-20].

The tests to characterize the physical and mechanical properties were performed following the recommendations of the B Annex of the standard ABNT NRB 7190[14]. Were investigated the following properties:

-Strength of parallel compression to the grain $\left(f_{c 0}\right)$;

-Modulus of elasticity in parallel compression to the grain $\left(E_{c 0}\right)$;

-Modulus of elasticity in normal compression to the grain $\left(E_{c 90)}\right.$;

-Strength of parallel tensile stress to the grain $\left(f_{t 0}\right)$;

-Longitudinal modulus of elasticity in parallel tensile stress to the grain $\left(E_{t 0}\right)$;

-Strength modulus in bending $\left(f_{M}\right)$;

-Bending modulus of elesticity $\left(E_{M 0}\right)$;

-Strength of normal co mp ression to the grain $\left(f_{c 90}\right)$;

-Strength of parallel shear stress to the grain $\left(f_{v 0}\right)$;

-Strength of normal tensile stress to the grain $\left(f_{t 90}\right)$;

-Strength ofcracking parallel to the grain $\left(f_{s o}\right)$;

-Bulk density $\left(\rho_{a p}\right)$;

-Retraction on radial $\left(\varepsilon_{\mathrm{r}, 2}\right)$ and tangential directions $\left(\varepsilon_{\mathrm{r}, 3}\right)$ to the grain;

-Parallel $\left(f_{H O}\right)$ and normal hardness to the grain $\left(f_{H 90}\right)$;

-Strength tensile $(W)$;

-Strength impact in bending $\left(f_{b w}\right)$.

For each one of the 18 properties analysed, there were 12 samples[12], what resulted in 216 tests per species analysed.

\section{Results and Conclusions}

Tables from 1 to 5 present the average results $\left(X_{m}\right)$, standard deviations (SD), and variation coefficients (VC) of each one of the properties analysed per species.

Table 1. Properties of Canelão wood species

\begin{tabular}{cccc}
\hline Properties & $\mathbf{X}_{\mathbf{m}}$ & SD & VC \\
\hline$\rho_{a p}\left(g / \mathrm{cm}^{3}\right)$ & 0,77 & 0,06 & 0,08 \\
$\varepsilon_{r, 2}(\%)$ & 3,52 & 0,62 & 0,17 \\
$\varepsilon_{r, 3}(\%)$ & 7,12 & 0,78 & 0,11 \\
$f_{c 0}(M P a)$ & 53 & 5 & 0,10 \\
$f_{t 0}(M P a)$ & 90 & 19 & 0,21 \\
$f_{c 90}(M P a)$ & 5,5 & 1,0 & 0,18 \\
$f_{t 90}(M P a)$ & 3,3 & 1,0 & 0,30 \\
$f_{v 0}(M P a)$ & 12,1 & 2,4 & 0,20 \\
$f_{s o}(M P a)$ & 0,5 & 0,12 & 0,22 \\
$f_{M}(M P a)$ & 97 & 10 & 0,10 \\
$E_{c o}(M P a)$ & 20036 & 3242 & 0,16 \\
$E_{t 0}(M P a)$ & 16522 & 1846 & 0,11 \\
$E_{c 90}(M P a)$ & 586 & 139 & 0,24 \\
$E_{M 0}(M P a)$ & 15355 & 621 & 0,04 \\
$f_{H 0}(M P a)$ & 53 & 8 & 0,15 \\
$f_{H 90}(M P a)$ & 50 & 8 & 0,16 \\
$W(N . m)$ & 29 & 5 & 0,16 \\
$f_{b w}\left(K J / m{ }^{2}\right)$ & 74 & 11 & 0,16 \\
\hline & & &
\end{tabular}


Table 2. Properties of Envira Branca wood species

\begin{tabular}{cccc}
\hline Properties & $\mathbf{X}_{\mathbf{m}}$ & SD & VC \\
\hline$\rho a p\left(g / \mathrm{cm}^{3}\right)$ & 0,91 & 0,06 & 0,07 \\
$\varepsilon r, 2(\%)$ & 5,10 & 0,55 & 0,11 \\
$\varepsilon r, 3(\%)$ & 8,69 & 0,64 & 0,07 \\
$f c 0(\mathrm{MPa})$ & 67 & 6,69 & 0,10 \\
$f t 0(\mathrm{MPa})$ & 154 & 28,31 & 0,18 \\
$f c 90(\mathrm{MPa})$ & 5,8 & 0,72 & 0,12 \\
$f t 90(\mathrm{MPa})$ & 4,0 & 0,99 & 0,25 \\
$f v 0(\mathrm{MPa})$ & 17,0 & 2,18 & 0,13 \\
$f s 0(\mathrm{MPa})$ & 0,6 & 0,08 & 0,12 \\
$f M(\mathrm{MPa})$ & 1253 & 268 & 0,21 \\
$E c 0(\mathrm{MPa})$ & 18328 & 3049 & 0,17 \\
$E t 0(\mathrm{MPa})$ & 18022 & 1144 & 0,06 \\
$E c 90(\mathrm{MPa})$ & 620 & 103 & 0,17 \\
$E M 0(\mathrm{MPa})$ & 14973 & 1800 & 0,12 \\
$f H 0(\mathrm{MPa})$ & 70 & 8,6 & 0,12 \\
$f H 90(\mathrm{MPa})$ & 50 & 5,8 & 0,12 \\
$W(\mathrm{~N} . \mathrm{m})$ & 30 & 4,4 & 0,15 \\
$f b w\left(\mathrm{~kJ} / \mathrm{m}^{2}\right)$ & 89 & 12,3 & 0,14 \\
\hline
\end{tabular}

Table 3. Properties of Quaruba Rosinha wood species

\begin{tabular}{cccc}
\hline Properties & $\mathbf{X}_{\mathbf{m}}$ & SD & VC \\
\hline$\rho_{\mathrm{ap}}\left(\mathrm{g} / \mathrm{cm}^{3}\right)$ & 0,62 & 0,04 & 0,07 \\
$\varepsilon_{\mathrm{r}, 2}(\%)$ & 3,45 & 0,34 & 0,10 \\
$\varepsilon_{\mathrm{r}, 3}(\%)$ & 5,97 & 0,70 & 0,12 \\
$f_{\mathrm{c} 0}(\mathrm{MPa})$ & 58 & 10 & 0,17 \\
$f_{\mathrm{t} 0}(\mathrm{MPa})$ & 114 & 24 & 0,21 \\
$f_{\mathrm{c} 90}(\mathrm{MPa})$ & 4,8 & 0,9 & 0,18 \\
$f_{\mathrm{t} 0}(\mathrm{MPa})$ & 4,9 & 1,2 & 0,25 \\
$f_{\mathrm{vo}}(\mathrm{MPa})$ & 10,5 & 2,0 & 0,22 \\
$f_{\mathrm{s} 0}(\mathrm{MPa})$ & 0,7 & 0,20 & 0,30 \\
$f_{\mathrm{M}}(\mathrm{MPa})$ & 93 & 10 & 0,11 \\
$E_{\mathrm{co}}(\mathrm{MPa})$ & 21846 & 4057 & 0,19 \\
$E_{\mathrm{t} 0}(\mathrm{MPa})$ & 20109 & 2277 & 0,11 \\
$E_{\mathrm{c} 90}(\mathrm{MPa})$ & 541 & 130 & 0,24 \\
$E_{M 0}(M P a)$ & 17884 & 1597 & 0,09 \\
$f_{H 0}(M P a)$ & 66 & 8 & 0,12 \\
$f_{H 90}(M P a)$ & 42 & 8 & 0,19 \\
$W(N . m)$ & 26 & 5 & 0,20 \\
$f_{b w}\left(K J / m^{2}\right)$ & 64 & 13 & 0,20 \\
\hline
\end{tabular}

Table 4. Properties of Guajará wood species

\begin{tabular}{cccc}
\hline Properties & $\mathbf{X}_{\mathbf{m}}$ & SD & VC \\
\hline$\rho_{a p}\left(g / \mathrm{cm}^{3}\right)$ & 0,68 & 0,03 & 0,04 \\
$\varepsilon_{r, 2}(\%)$ & 4,07 & 0,41 & 0,10 \\
$\varepsilon_{r, 3}(\%)$ & 7,67 & 0,64 & 0,08 \\
$f_{c 0}(M P a)$ & 58 & 7 & 0,12 \\
$f_{t 0}(M P a)$ & 116 & 29 & 0,25 \\
$f_{c 90}(M P a)$ & 7,0 & 1,3 & 0,19 \\
$f_{t 90}(M P a)$ & 4,6 & 1,3 & 0,29 \\
$f_{v 0}(M P a)$ & 13,2 & 1,9 & 0,14 \\
$f_{M}(M P a)$ & 108 & 12,4 & 0,11 \\
$E_{c 0}(M P a)$ & 22524 & 5313 & 0,24 \\
$E_{t o}(M P a)$ & 16486 & 2921 & 0,18 \\
$E_{c 90}(M P a)$ & 863 & 169 & 0,20 \\
$E_{M 0}(M P a)$ & 18467 & 5388 & 0,29 \\
$f_{H 90}(M P a)$ & 60 & 9,0 & 0,14 \\
$W(N . m)$ & 29 & 6,6 & 0,23 \\
$f_{b w}\left(k J / m^{2}\right)$ & 73 & 16,6 & 0,23 \\
\hline
\end{tabular}

Table 5. Properties of Breu Vermelho wood species

\begin{tabular}{cccc}
\hline Properties & $\mathbf{X}_{\mathbf{m}}$ & SD & VC \\
\hline$\rho_{a p}\left(g / \mathrm{cm}^{3}\right)$ & 0,79 & 0,03 & 0,04 \\
$\varepsilon_{r, 2}(\%)$ & 5,24 & 1,10 & 0,21 \\
$\varepsilon_{r, 3}(\%)$ & 6,51 & 1,03 & 0,16 \\
$f_{c 0}(M P a)$ & 89 & 5,5 & 0,06 \\
$f_{t 0}(M P a)$ & 89 & 22 & 0,25 \\
$f_{c 90}(M P a)$ & 10 & 2,1 & 0,21 \\
$f_{t 90}(M P a)$ & 7,4 & 2,2 & 0,29 \\
$f_{v 0}(M P a)$ & 22,9 & 2,4 & 0,11 \\
$f_{s 0}(M P a)$ & 0,93 & 0,26 & 0,28 \\
$f_{M}(M P a)$ & 119 & 12 & 0,10 \\
$E_{c o}(M P a)$ & 13142 & 2595 & 0,20 \\
$E_{t 0}(M P a)$ & 16569 & 2088 & 0,13 \\
$E_{c 90}(M P a)$ & 589 & 122 & 0,21 \\
$E_{M 0}(M P a)$ & 16386 & 1305 & 0,08 \\
$f_{H 0}(M P a)$ & 121 & 5 & 0,04 \\
$f_{H 90}(M P a)$ & 82 & 6 & 0,07 \\
$W(N . m)$ & 28 & 10 & 0,36 \\
$f_{b w}\left(k J / m{ }^{2}\right)$ & 70 & 27 & 0,38 \\
\hline
\end{tabular}

Figures 1 and 2 shows the results of the linear regression between density and strength compression parallel to the grain and density and strength tensile parallel to the grain for Canelão wood species.

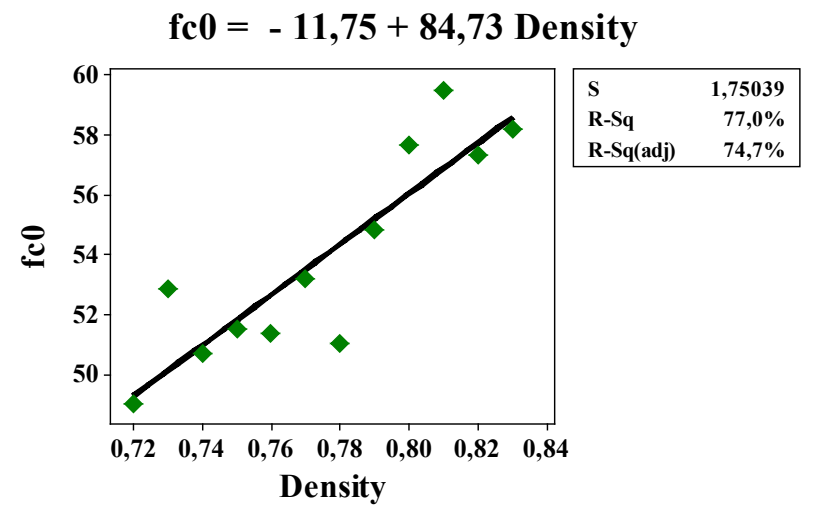

Figure 1. Linear regression between density and strength compression parallel to the grain of Canelão wood species

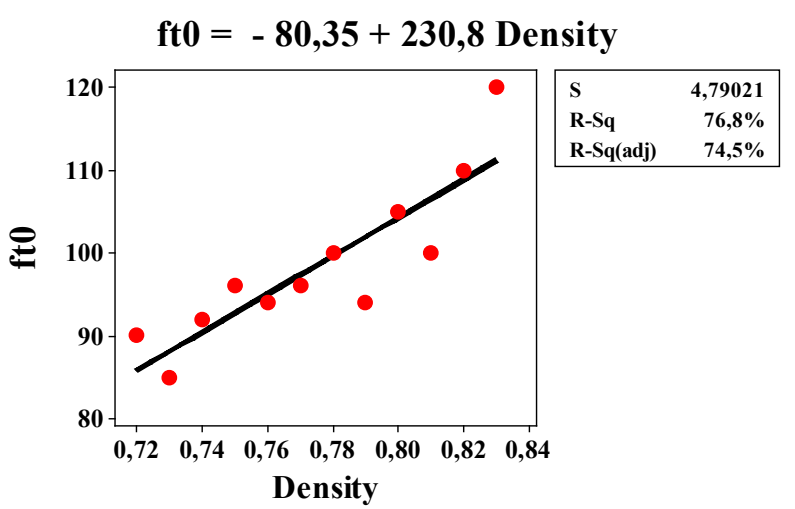

Figure 2. Linear regression between density andstrengthtensile parallel to the grain of Canelão wood species 
Figures 3 and 4 shows the results of the linear regression between density and strength compression parallel to the grain and density and strength tensile parallel to the grain for Envira Branca wood species.

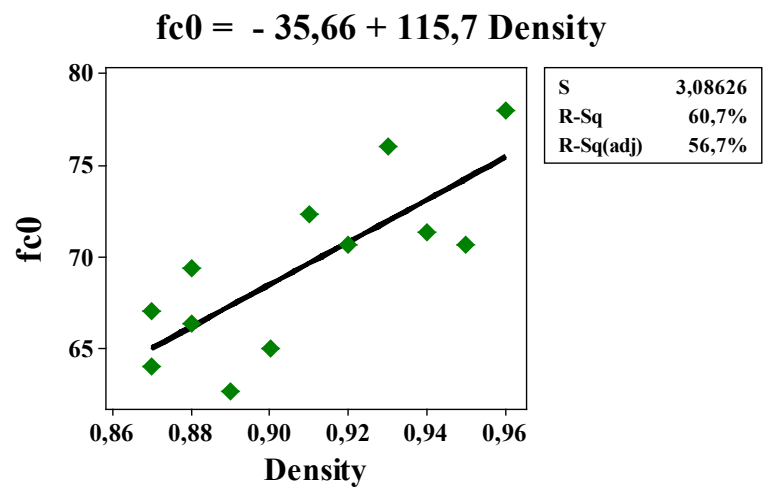

Figure 3. Linear regression between density and strength compression parallel to the grain of Envira Branca wood species

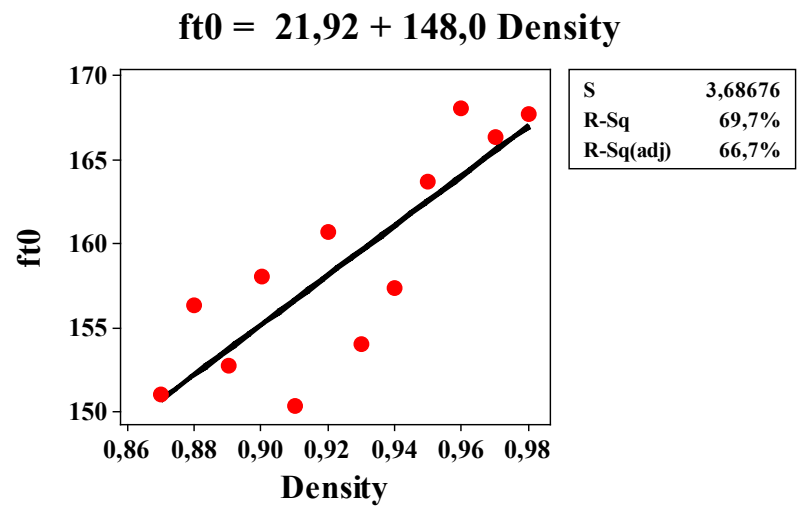

Figure 4. Linear regression bet ween density andstrengthtensile parallel to the grain of Envira Branca wood species

Figures 5 and 6 shows the results of the linear regression between density and strength compression parallel to the grain and density and strength tensile parallel to the grain for Quaruba Rosinha wood species.

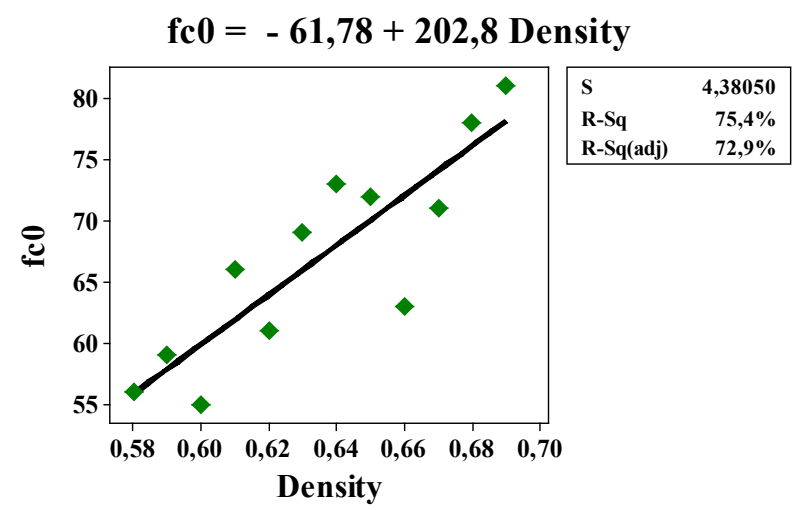

Figure 5. Linear regression between density and strength compression parallel to the grain of Quaruba Rosina wood species

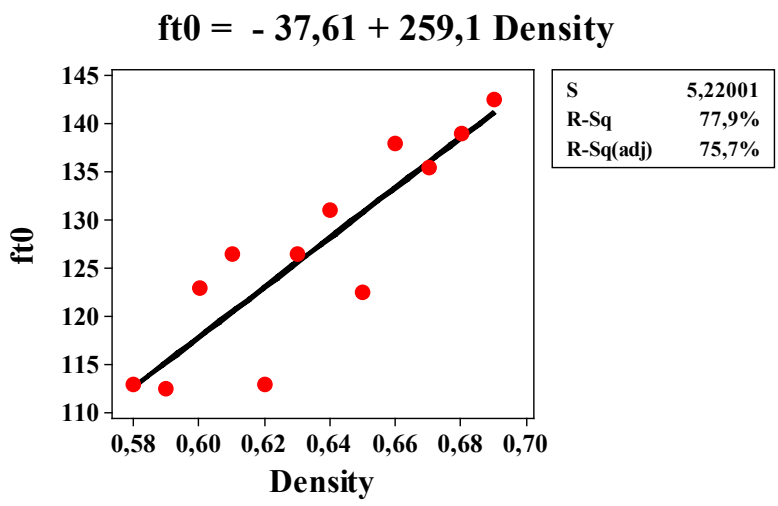

Figure 6. Linear regression between density and strength tensile parallel to the grain of Quaruba Rosinha wood species

Figures 7 and 8 shows the results of the linear regression between density and strength compression parallel to the grain and density and strength tensile parallel to the grain for Guajará wood species.

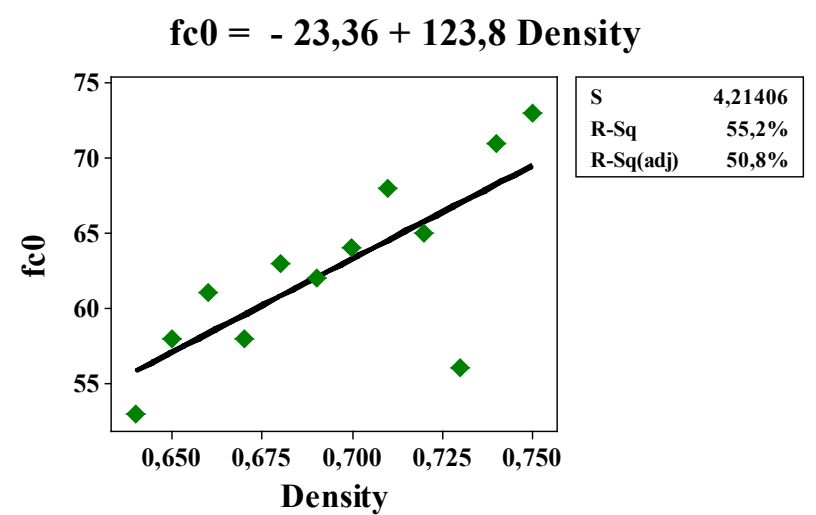

Figure 7. Linear regression between density and strength compression parallel to the grain of Guajará wood species

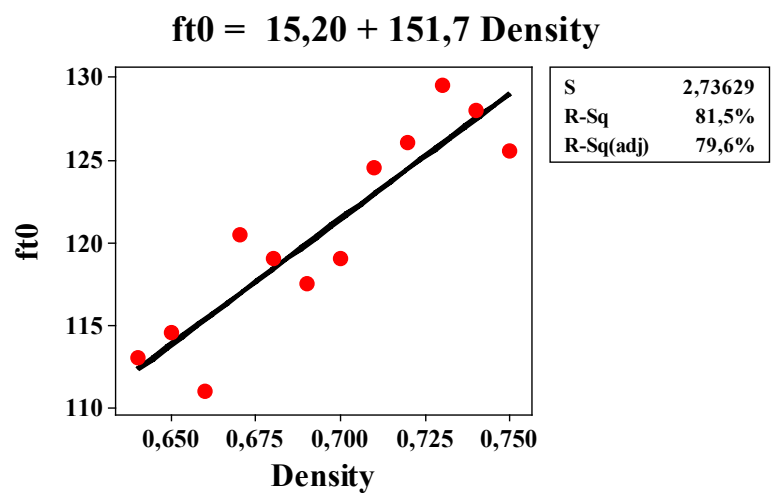

Figure 8. Linear regression between density and strength tensile parallel to the grain of Guajará wood species

Figures 9 and 10 shows the resultsof the linear regression between density and strength compression parallel to the grain and density and strength tensile parallel to the grain for Breu Vermelho wood species. 


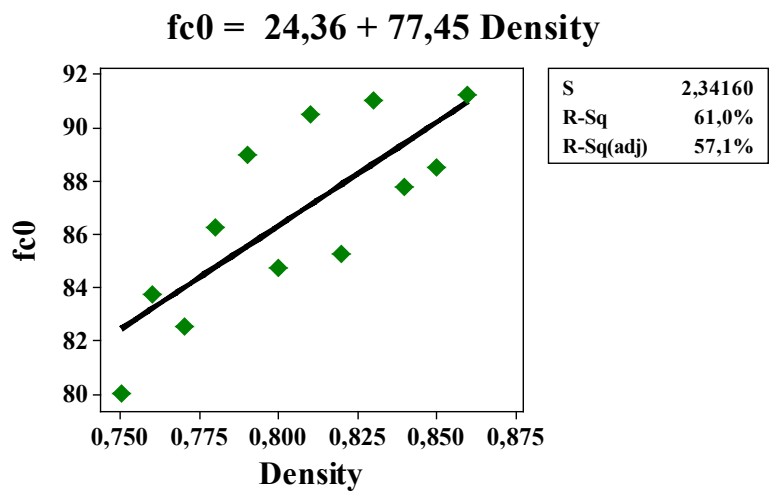

Figure 9. Linear regression between density and strength compression parallel to the grain of Breu Vermelho wood species

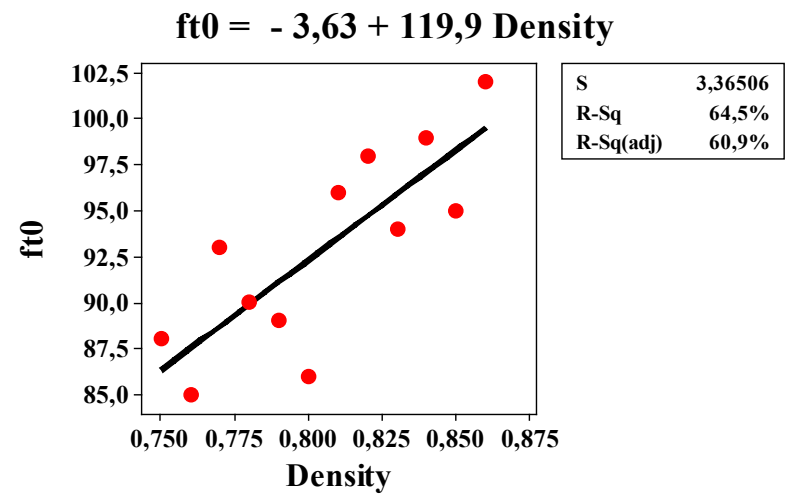

Figure 10. Linear regression between density and strength tensile parallel to the grain of Breu Vermelho wood species

\section{Conclusions}

Considering the resultsobtained from regression between density andstrengthtensile parallel to the grain ofGuajará wood species of the physical and mechanical properties of the five species analysed, it is possible to conclude that:

-Canelão, Guajará and Breu Vermelho wood species can be compared to OiticicaAmarela and AngelimPedra, two species usually employed in Brazilian structures;

-Quaruba Rosinhawood species can be compared to Quarubarana and LouroPreto, two species usually employed in Brazilian structures;

-Envira Branca wood species can be compared to Canafístula e Guarucaia, also species commonly present in Brazilian structural constructions.

According with the results, the timber species originated fro $m$ North of MatoGrosso (Brazil) that were investigated on this work, can be employed in structural projects substituting with the same or superior performance the species commonly used.

The results of the linear regression between density and tensile and comp ression strength parallel to the gra in indicate that is possible determine the strength properties with knowledge the of de density of the wood species investigated.

\section{ACKNOWLEDGEMENTS}

The authors are grateful to the Syndicate of Timber Industries of North MatoGrosso (SINDUSMAD) for providing the wood species required for this research.

\section{REFERENCES}

[1] M. H. Souza, "Incentivo ao uso de novas madeiras para a fabricação de móveis". IBAMA, Brasília, 70p, 1997.

[2] F. A. Rocco Lahr, "Propriedades físicas de resistência e de elasticidade de espécies de madeira para emprego em estruturas". In: Encontro Brasileiro em Madeiras e em Estruturas de Madeira, v.3, São Carlos, SP, Brasil, 1989.

[3] D. Goncalves, C. Calil Jr, F. A. Rocco Lahr, N. Calil Jr., "Madeira como material essencial para uma Arquitetura Bioclimática". In: FourthAmazon Green Materials, Manaus. AM. v. 1. Brasil, 2012.

[4] Instituto Brasileiro de Desenvolvimento Florestal - IBDF. http://www.ip ef.br/legislacao/bdlegislacao/?No_Pai=28\&Ca minho $=25,2,1,0$.

[5] F. A. Rocco Lahr, J. O. Barros, "Considerações sobre a utilização de madeiras na construção de estruturas de cobertura para conjuntos habitacionais". In: Encontro Brasileiro em Madeiras e em Estruturas de Madeira, 4, São Carlos, SP, Brasil, 1992.

[6] F. A. Rocco Lahr, A. A. Dias, A. L. Zangiácomo, C. E. Radaik, "Caracterização de espécies alternativas de madeira para emprego em estruturas". In: Encontro Brasileiro em Madeiras e em Estruturas de Madeira, 7, São Carlos, SP, Brasil, 2000.

[7] F. A. Rocco Lahr, O. Barros Jr., J. F. Nascimento, A. M. Piovisan, "Propriedades estruturais de três espécies alternativas de madeira - parte 2". In: Encontro Brasileiro em Madeiras e em Estruturas de Madeira, 4, São Carlos, SP, Brasil, 1992.

[8] F. R. Rocco Lahr, D. G. Robles, "Characterization of alternative species of wood for employment in civil construction". In: International Symposium on Natural Polymers and Composites, 2, Atibaia, SP, Brasil, 1998.

[9] F. A. Rocco Lahr, A. A. Dias, "Maderastropicalesbrasileñas alternativas". Madera: Ciencia y Tecnología, Universidad del Bío-Bío, Chile, vol.1, n.2, p.7-14. ISSN 0735-205X, 1999.

[10] Z. Finger, N. B. Logsdon, M. S. Rodrigues, M. L. R. Cruz, "Caracterização mínima da resistência e simplificada da rigidez". In: Encontro Brasileiro em Madeiras e em Estruturas de Madeira, 10, São Pedro, SP, Brasil, 2006.

[11] F. G. R. Oliveira, A. Sales, "Ultrassonic measurements in Brazilian hardwood", Materials and Research, v. 5, n. 1, p. 51-55, 2002.

[12] A. J. S. Miná, F. G. R. Oliveira, C. Calil Jr, A. A. Dias, A. Sales, "Avaliação não destrutiva de postes de madeira por meio de ultrassom", ScientiaForestalis, n. 65, p. 188-196, 2004.

[13] Instituto Nacional de Pesquisas Espaciais (INPE). 
http ://www.ipef.br/legislacao/bdlegislacao/?No_Pai=28\&Ca $\operatorname{minho}=25,2,1,0$.

[14] Associação Brasileira De Normas Técnicas (ABNT). Projeto de Estruturas de Madeira, NBR 7190, Rio de Janeiro, 65 p, 1997.

[15] A. L. Christoforo, A. A. Rocco Lahr, E. A. M Morales, A. L. Zangiácomo, T. H. Panzera, "Influence of Displacements on Calculus of the Longitudinal Modulus of Elasticity of Pinus Caribaea Structural Round Timber Beams". International Journal of Agriculture and Forestry, v. 2, p. 157-160, 2012.

[16] A. L. Christoforo, F. A.Rocco Lahr, E. A. M. Morales, T.H. Panzera, P. H. R Borges, "Numerical Evaluation of Longitudinal Modulus of Elasticity of Eucalyptus grandis Timber Beams". International Journal of Agriculture and Forestry, v. 2,p. 166-170, 2012.
[17] A. J. S. Miná, A. A. Dias, "Estacas de madeira para fundações de pontes de madeira.Cadernos de Engenharia de Estruturas, v.10, p.129-155, 2008.

[18] A. L. Zangiácomo, F. A. Rocco Lahr, "Avaliação do efeito de cisalhamento na flexão de elementos roliços da espécie Eucalyptus citriodora. In: Encontro Brasileiro Em Madeiras E Em Estruturas De Madeira, 9, Londrina, 2008.

[19] M. R. Carreira, A. A. Dias, "Avaliação da rigidez à flexão de toras de madeira por meio de vibração transversal". Cadernos de Engenharia de Estruturas, São Carlos, v.11, p.75-79, 2009.

[20] A. Sales, T. R. Pelizan, F. G. R. Oliveira, M. Candian, F. F. Lucchette, J. L. Salgon, K. P. Miller, "Avaliação de propriedades mecânicas de peças roliças de Eucalipto por meio de ultrassom". In: Encontro Brasileiro em Madeiras e em Estruturas de Madeira, 9. Cuiabá, 2004. 